\title{
ŚW. JAN KANTY W ŚWIETLE NAJNOWSZYCH BADAŃ*
}

Niemal ${ }^{1}$ dokładnie sto lat temu, 2 maja 1890 roku, wielce zasłużony historyk i bibliotekarz krakowski dr Władysław Wisłocki wygłosił na posiedzeniu Wydziału Historyczno-Filozoficznego Akademii Umiejętności w Krakowie drugą z czterech prelekcji, opublikowanych niebawem kolejno pod wspólnym tytułem: Jan z Kęt Wacięga, w Sprawozdaniach z posiedzeń Akademii Umiejętności w Krakowie za rok 1890. Wisłocki przedstawił w swoich wystąpieniach nową wersję żywota św. Jana Kantego w sposób równie erudycyjny co autorytatywny, opierając się przy tym na własnej interpretacji odnośnych źródeł historycznych, a zwłaszcza autografów mistrza z Kęt, zidentyfikowanych przez siebie w 16 (właściwie 17) rękopisach Biblioteki Jagiellońskiej podczas katalogowania manuskryptów w niej przechowywanych (owocem tej pracy Wisłockiego jako bibliotekarza-archiwisty był do dziś pożytkowany przez historyków dwutomowy Katalog rękopisów Biblioteki Uniwersytetu Jagiellońskiego, Kraków 1877 -1881). Swoim słuchaczom przedstawił on koleje życia i działalności naukowo-kościelnej Jana Kantego, właściwie pozbawione znaków zapytania.

A przecież już sferą hipotetycznych domysłów należy objąć dzieciństwo i młodość przyszłego profesora Akademii Krakowskiej. Jedynie rok urodzenia 1390 wydaje się tu pewny, gdyż pośrednio określił go sam Jan Kanty w kilku kolofonach, pisząc np. w jednym $\mathrm{z}$ nich:

* Poniższy tekst jest nieco poszerzoną wersją odczytu, wygłoszonego $10 \mathrm{~V} 1990 \mathrm{w}$ auli Domu Parafialnego przy kolegiacie św. Anny w Krakowie podczas sesji naukowej, zorganizowanej przez proboszcza parafii św. Anny Księdza Prałata Władysława Gasidłę i Wydział Historii Kościoła Papieskiej Akademii Teologicznej w Krakowie.

${ }^{1}$ Ponieważ wszystkie niemal przypisy odnosilyby się do tej samej grupy publikacji naukowych, zestawiam je poniżej w alfabetycznej kolejności, odsyłając do nich zainteresowanych Czytelników: B. B os s u e, De s. Ioanne Cantio, [w:] Acta Sanctorum Octobris, vol 8, Parisiis et Romae 1866, s. 1042 - 1106; M. Re ch ow ic z, Jan Kanty, [w:] Hagiografia polska, t. 1, Poznań - Warszawa - Lublin 1971; tenże, Jan z Kęt, [w:] Polski stownik biograficzny, t. 10, Warszawa 1963, s. $456 \mathrm{n}$.; W. Wisł oc ki, Jan z Kęt Wacięga, [w:] Sprawozdania z posiedzeń Akademii Umiejętności w Krakowie za rok 1890. Wydziat Historyczno-Filozoficzny, Kraków 1891, s. 17 - 23, 29 - 41, 46 - 48; R. Z a w a d z ki, Stan badań nad życiem i spuściznq rękopiśmienna św. Jana z Kęt, „Analecta Cracoviensia" 5/6 : 1973/4 s. 7 - 48; tenże, Jagiellońskie rękopisy Jana Kantego w zbiorach watykańskich, „Biuletyn Biblioteki Jagiellońskiej”26:1976 s. 23-35; tenże, Św. Jan z Kęt-nauczyciel $i$ kaptan (1473 - 1973), „Roczniki Teologiczno-Kanoniczne KUL” $22: 1975$ z. 6 s. 5-16. 
Expositio super Mattheum [...] finita in die beati Hieronimi [30 IX] doctoris eximii per Johannem Kanti, collegam magistrorum Collegii Artistarum a. D.

$\mathrm{MCCCCLXI}^{\circ}$, aetatis vero suae anno septuagesimo primo currenti $[\ldots]$

Natomiast hipotetyczna jest data dzienna jego urodzin. Tradycja łączyła imię naszego Patrona ze św. Janem Chrzcicielem. Dlatego przyjmuje się dzień 24 czerwca 1390 roku jako pełną datę urodzenia Jana Kantego. Wisłocki jednak podważył tę datację, utrzymując, że „patriarcha uniwersytecki nie mógł dnia tego [24 VI] przyjść na świat z tej prostej przyczyny, że patronem jego nie był św. Jan Baptysta; według pieczęci bowiem, dotąd szczęśliwie w Archiwum UJ przechowanej, pieczętował się Kanty orłem z nimbem nad głową, symbolem św. Jana Ewangelisty, i mógł się był urodzić albo 27 grudnia, albo w dzień, zwany uroczystością św. Jana w Oleju, czyli 6 maja”. Wprawdzie owa informacja o rzekomej pieczęci własnej Jana Kantego (nieszlachcica!) polega na całkowitym nieporozumieniu, to jednak Wisłocki, przekonany o słuszności swej „naukowej” argumentacji, przesunął datę urodzin Jana Kantego na 27 grudnia $1389 \mathrm{r}$.

W świetle dostępnej nam dokumentacji historycznej dzieciństwo i młodość św. Jana Kantego stanowią nadal białą plamę. Nie istniała ona wszakże dla Wisłockiego. Wypełnił ją obrazami, o jakich ledwie marzyć może historyk. Zaczął od zmiany miejsca urodzenia naszego Patrona. W XVII-wiecznej kopii kilku kolofonów z Janowych rękopisów (te ostatnie zostały w roku 1728 wywiezione do Rzymu celem uzupełnienia dokumentacji kanonizacyjnej i nigdy już stamtąd nie powróciły do Krakowa) znalazł Wisłocki następujący zapis (dzisiaj występujący w rękopisie Biblioteki Watykańskiej Vat. Lat. 14647 f. 81 v):

Finis huius in crastino s. Stanislai in vere $[9 \mathrm{~V}]$ in schola Mechowiensi [...] anno Domini MCCCC27 [...] Johannes Maleus alias Kanthy.

Na postawie tego kolofonu przeniósł Wisłocki miejsce urodzin św. Jana Kantego do pobliskiego przysiółka Malec. Jednakowoż pomienioną supozycję skomplikował mu inny kolofon, odpisany przez notariuszy uniwersyteckich w XVII w. Otóż w dzisiejszym rękopisie watykańskim Lat. 14642 widnieje kolofon, w którym wymieniono kopistę kilku ksiąg biblijnych. Wiemy, że był nim niejaki Jan z Warty, były student Akademii Krakowskiej (od 1423 r.), bakałarz sztuk wyzwolonych (1425) i prawdopodobnie następca Jana Kantego na rektorstwie szkoły bożogrobców miechowskich. Inaczej jednak odczytali ten kolofon kopiści XVII-wieczni, toteż za nimi podał Wisłocki, że ową część Biblii przepisał niejaki Jan z Marty, według historyka krakowskiego — identyczny z naszym Janem Kantym. Wisłocki nie powołał się przy tym (jak zresztą przy dalszych rewelacjach) na znane źródła historyczne. Stwierdził po prostu, że Malec i Marta są nazwami synonimicznymi, zamiennie używanymi przez lud- 
ność miejscową. Ponadto można je etymologicznie wywieźć z rumuńskiego malu i z węgierskiego mart, co w obu językach rzeczywiście znaczy brzeg rzeki (jak wiadomo, Kęty i Malec leżą na Sołą). Podziwiać można erudycję Wisłockiego, lecz nierównie więcej dziwić się należy brakowi krytycyzmu i ostrożności w ferowaniu swoich hipotez. Mimo że wspomniani wyżej XVII-wieczni kopiści uniwersyteccy sami przyznali się do własnej ignorancji paleograficznej, przerywając przepisywanie rękopisów Jana Kantego dla potrzeb procesu kanonizacyjnego, Wisłocki zaufał im bezkrytycznie. Udostępnione przed 20 laty rękopisy św. Jana Kantego przez Bibilotekę Watykańską (niestety nie miałem ich nigdy w rękach, ale mogłem skorzystać z mikrofilmów) pozwoliły wyjaśnić ostatecznie sprawę owego „Jana z Marty”, a także rzeczowo ustosunkować się do własnoręcznego podpisu naszego Patrona w formie: Joannes Maleus alias Kanthy. Lekcja ta z paleograficznego punktu widzenia nie nastręcza większych trudności. Problem zaś leży w tym, że pozostała zupełnie nie znana tradycji i legendzie narosłej wokół postaci św. Jana Kantego, co więcej — ujawniona pod koniec XVII wieku nie wzbudziła niczyjego zainteresowania. Natomiast analizując ten zapis z filologicznego punktu widzenia, można jedynie powiedzieć, że wyraz Maleus nie może być nazwą odmiejscową, gdyż przymiotnikowa forma od rzeczownika Malec musiałaby brzmieć po łacinie: Malecensis, ewentualnie Malecius, Malcius - nigdy Maleus. Jan Kanty zbyt dobrze znał łacinę (nawet jeśli to była tylko łacina jego epoki), by taki błąd popełnić. Należy zatem przyjąć, że chodzi tu o lekcję malleus (młot, topór), pełniącą tu rolę przydomka (przezwiska); nie była ona antroponimizacją nazwy miejscowej w funkcji nazwiska.

Próbując ustalić dalsze fakty, odnoszące się do najwcześniejszych lat Jana Kantego, Wisłocki sięgnął także po Acta Sanctorum, gdzie w ósmym tomie października (ukazał się drukiem w roku 1866!) znalazł obszerny artykuł Beniamina Bossue o św. Janie Kantym. Wśród licznych materiałów historycznych, przedrukowanych przez autora, znalazł się fragment tekstu, wyjęty z papierów pozostawionych przez Bollandusa, choć nie jego autorstwa. Krótko rzecz ujmując, sprawa przedstawiała się następująco. Około roku 1603 krakowski jezuita Fryderyk Schembek (nb. zaciekły przeciwnik Akademii Krakowskiej, ale przy tym wielki czciciel św. Jana Kantego) sporządził dla Herberta Rosweya, właściwego inicjatora monumentalnych Acta sanctorum, kilka biogramów świętych polskich, do których zaliczył nie kanonizowanego jeszcze Jana Kantego. Otóż właśnie w życiorysie tego ostatniego podał Schembek nie wiadomo skąd wygrzebaną informację o tym, że ojciec naszego Patrona był rajcą kętskim i nazywał się Stanisław Wacięga (Stanislaus Vacenga), matka zaś miała na imię Anna. Już dla niej „nazwisko”, niezbyt zresztą estetyczne, wymyślił oczywiście Wisłocki, a mianowicie - Sramówna. Za naukowy argument posłużył mu w tym wypadku jednostkowy zapis w Album studiosorum Universitatis Cracoviensis (t. 1, Cracoviae 1887, s. 85), z którego wynikało, że w roku 1434 wpi- 
sał się na Krakowski Uniwersytet niejaki „Nicolaus Petri Sram de Canti”. Zdaniem Wisłockiego, w Kętach i okolicy mieszkało mnóstwo Sramów, więc matka Jana z Kęt musiała się też tak nazywać!

Odtąd opowieść Wisłockiego o młodzieńczych latach przyszłego profesora Akademii Krakowskiej zaczęła nabierać coraz żywszej i barwniejszej narracji. Wiemy już, że miejsce urodzin Jasia Wacięgi przeniósł z Kąt do pobliskiego Malca, a że tam nie było kościoła, więc kazał go rodzicom ochrzcić w Osieku. Natomiast nie wiedzieć czemu zdegradował starego Wacięgę do stanu bezrolnego chłopa (takich nazywano wówczas hultajami, ale dla naszego historyka synonimem tego określenia mieli być macięg owie i wacięgowie, jakich rzekomo pełno było w tej okolicy, o czym dotąd nie wiedzieliśmy i nadal nie wiemy). Ale Stanisławowi Waciędze się w końcu poszczęściło, bo - jak twierdzi Wisłocki - otrzymał on posadę kościelnego w Kętach „,z obowiązkiem dzwonienia na nabożeństwa i Anioł Pański [...] zamiatania kościoła, odgarniania zimową porą śniegów, rąbania drwa, palenia w piecach u księdza proboszcza i księży wikarych". Pozostawiając na boku te wręcz filmowe opowieści o rodzinnym domu św. Jana Kantego, ograniczę się tylko do krytyki tezy o nazwisku Wacięga.

Wisłocki popełnił dwa błędy, obdarzając mistrza Jana tym nazwiskiem: jeden to błąd metodyczny, drugi - historyczny. Błąd metodyczny polegał na tym, że w czasy średniowieczne przeniósł prawno-ustrojowe uwarunkowania XIX wieku, kiedy to każda osoba musiała mieć nazwisko, najczęściej dziedziczone po ojcu. Błąd historyczny natomiast polegał na tym, że nazwiska mieszczan polskich pojawiają się dopiero w XV wieku i początkowo nie były w ogóle dziedziczne. Nazwisko Wacięga, choć zanotował je na początku XVII wieku jezuita Schembek, nie zostało dotąd potwierdzone w żadnym innym zapisie. Najlepszym tego dowodem jest kartoteka Zakładu Onomastyki PAN w Krakowie, w której ta nazwa imienna figuruje wynotowana... z książki telefonicznej. Inaczej mówiąc, nie jest znana dzisiejszym onomastom i historykom XIXwieczna lub wcześniejsza forma nazwiska Wacięga. Spopularyzował ją mimowolnie dopiero Władysław Wisłocki przez opublikowanie w roku 1890 tekstu swych odczytów o św. Janie z Kęt. Można więc powiedzieć, że wielce przysłuży się polskiej onomastyce ten, kto wskaże na wcześniejszy zapis nazwy Wacięga (pominąwszy ów podany przez Fryderyka Schembeka, nie potwierdzony w innych źródłach). Niezależnie jednak od rezultatów takich poszukiwań nikt nie będzie mógł twierdzić, że św. Jan Kanty nosił po ojcu jakiekolwiek nazwisko, bo wówczas, pod koniec XIV wieku taki zwyczaj w polskim nazewnictwie rodzinnym po prostu nie istnial.

Wisłocki był jednak głęboko przekonany o naukowym walorze swoich wywodów na temat rodziny św. Jana z Kęt. Przedstawil je — trzeba to przyznać - w sposób nader sugestywny i przekonywający. Nie zaszkodziła im ani twórcza krytyka ówczesnego proboszcza od św. Anny ks. dra Juliana Bukowskiego, 
opublikowana w kilka miesięcy po wykładach Wisłockiego w tychże samych Sprawozdaniach z posiedzeń Akademii Umiejętności w Krakowie, ani dyskusje późniejszych historyków, na ogół uważających, że Wisłocki powiedział ostatnie słowo w zakresie biografii św. Jana Kantego. Ostatecznie większość tez Wisłockiego została usankcjonowana najpierw w X tomie Polskiego słownika biograficznego (1963) następnie w I tomie Hagiografii polskiej (1971) i odtąd są bezkrytycznie powtarzane przez autorów wielu uczonych i wartościowych skądinąd opracowań mediewistycznych, a także hagiograficznych.

W istocie rzeczy św. Jan Kanty jako postać historyczna pojawia się dopiero w roku 1413, kiedy to sławny Stanisław ze Skarbimierza, podówczas rektor (por raz wtóry) krakowskiego Studium Generale, wpisał go w poczet studentów Wydziału Sztuk Wyzwolonych tej uczelni. Tak więc Jan z Kęt zapłaciwszy wpisowe w wysokości 6 gr. rozpoczął w 23 roku życia swoje studia uniwersyteckie. Dobre przygotowanie ogólne, a przy tym wrodzona pilność i zapewne talent pozwoliły mu ukończyć w przepisanym okresie pięciu lat kurs nauk na tymże Wydziale; w semestrze zimowym 1417/18 otrzymał tytuł magistra sztuk wyzwolonych - tytuł, którym mogło się w tym czasie poszczycić nie więcej jak $10 \%$ studentów, rozpoczynających naukę w krakowskim Studium Generalnym.

Kolejny okres życia mistrza Jana do roku 1421 znowu pozostaje czasem nie wypełnionym potwierdzonymi przez źródła faktami. Jeśli wierzyć wiadomości zamieszczonej w Breviarium historiae Tinecensis z początku XIX wieku (Ossolineum, rkps 480 f. 6), mistrz Jan Kanty otrzymał w tym czasie święcenia kapłańskie w Tuchowie. Aliści w roku 1421 został nieoczekiwanie zaangażowany na rektora szkoły klasztornej u bożogrobców miechowskich. Przebywał tam z górą lat siedem. Nie mając, jak się zdaje, zbyt wielu zajęć szkolnych i duszpasterskich, „dla uniknięcia nudy i lenistwa” (pro tedii et otii evitatione) zajął się, jak sam o tym wspomina w jednym z kolofonów, przepisywaniem rękopisów. Kiedy przegląda się dzisiaj 18 rękopisów przechowywanych w Bibliotece Jagiellońskiej i 10 - w Bibliotece Watykańskiej, będących w $90 \%$ autografami mistrza z Kęt z lat $1423-1463$, rodzi się podziw i zdumienie; podziw dla żmudnej pracy kopisty, wykonywanej nieraz po nocach, skoro znowu zanotował w jednym z rękopisów, że ukończył swą pracę w pierwszą sobotę po św. Andrzeju, „o nocnej porze, gdy już zaczynano śpiewać modlitwy poranne” (hora noctis dummodo matutinae decantabantur), zdumienie - gdy weźmiemy pod uwagę, że większość tych rękopisów wykonał Jan Janty jako profesor Akademii Krakowskiej.

Mistrz Jan nie był bezmyślnym kopistą. Przepisywane przez siebie teksty poprawiał, kolacjonował, opatrywał uwagami marginalnymi, dodawał aktualne notatki i sprostowania. Prócz składek przepisanych własnoręcznie, znajdujemy w jego rękopisach również takie, które pochodzą od innych, często jego uniwersyteckich kolegów (np. Zygmunta z Pyzdr, rkps BJ 325). Swiadczy to 
o jego zainteresowaniach naukowych, miłości do słowa pisanego, do książki w ogóle. Zebrana przezeń w ten sposób własna biblioteka prywatna, na owe czasy pod pewnym względem zupełnie wyjątkowa, a i co do ilości imponująca, pozostała jego własnością do końca życia. Dopiero po śmierci mistrza Jana przekazano ją, jak wiele innych ówczesnych bibliotek profesorskich, do zbiorów Kollegium Większego.

W ciągu 40 lat tego rodzaju działalności pisarskiej i bibliofilskiej Jan Kanty zgromadził księgozbiór obrazujący niejako prądy ideowe epoki, ale też ukazujący twórcze zainteresowania mistrza z Kęt jako nauczyciela i kapłana. Pouczający jest przegląd zawartości tych kodeksów. Pod wplywem religijnych sporów i dyskusji, rozpalających podówczas umysły teologów i polityków, przepisuje on traktaty husyckie i antyhusyckie. Te pierwsze wszakże zaleca czytać z największą ostrożnością. Kopiuje pisma uczestników soboru w Konstancji i Bazylei. Niejako tłem dla tych piętnastowiecznych aktualiów teologicznych w Janowych kodeksach są naturalnie traktaty patrystyczne. Dają nam one przejrzysty obraz formacji doktynalnej mistrza z Kęt. Zestawiając tytuły skopiowanych przez niego traktatów Ojców Kościoła, konstatujemy, że dominującą w nich rolę odgrywają dzieła św. Augustyna, nawet wtedy, kiedy się wydzieli z nich dzieła innych autorów, ale w czasach Jana Kantego uchodzące za pisma biskupa z Hippony. Zresztą patriarcha krakowski nieraz zaznaczał swe wątpliwości co do autorstwa przepisywanych tekstów, nie mówiąc już o tym, że czasem narzekał na trudno czytelny wzór, z jakiego dany tekst odpisywał (np. rkp. BJ 2375: „hic liber est in toto corruptus”). Warto może wspomnieć, że trud kopisty zaczął właśnie od jednego z traktatów św. Augustyna (Enchiridion, rkps BJ 2375).

Natomiast dzieła św. Tomasza z Akwinu wziął do przepisywania stosunkowo późno, w każdym razie po zakończeniu studiów teologicznych, czyli około połowy stulecia. W kodeksach wcześniejszych napotykamy jedynie na ekscerpty z pism Tomaszowych, zapewne odnotowywane dla własnych potrzeb podczas studiów teologicznych. Typowym przykładem kodeksu sporządzonego w takim właśnie celu jest rkps BJ 2603 zawierający wypisy z komentarzy do Sentencji Piotra Lombarda autorstwa św. Tomasza, Piotra z Tarantazji i Wilhelma z Autun (prócz tego jest tu także Summa de casibus conscientiae Bartłomieja $z$ Pizy).

$\mathrm{Z}$ niemałym natomiast zdziwieniem stwierdzamy zupełny brak pism Alberta Wielkiego w kodeksach Jana Kantego. Wskazywałoby to na fakt, że duchowa i intelektualna formacja naszego Patrona została ukształtowana nie na modnym podówczas szkotyzmie czy albertyzmie, ale na doktrynie św. Augustyna, dopełnionej teologiczną myślą Akwinaty. Stawia to św. Jana Kantego w rzędzie przedstawicieli humanizmu chrześcijańskiego, czyli tego nurtu intelektualnego w ówczesnej christianitas, który wiódł do prawdziwej odnowy chrześcijaństwa przez pełny nawrót do Pisma św. i do rzeczywistych źródeł chrześcijań- 
stwa, przez pełny ewangelizm, wypływający z wewnętrznego przeświadczenia i z pełnej, wewnętrznej wolności.

Równolegle do swej działalności skrypturystycznej Jan Kanty podejmował kolejne obowiązki uniwersyteckie. Wykłady na Wydziale Artium rozpoczął w roku 1429. W pięć lat później był już prepozytem Kollegium Większego. Dwukrotnie pełnił funkcję dziekana Wydziału Sztuk Wyzwolonych (1432/3, $1437 / 8)$. Nie dość tego, mając z górą lat 40 podjął studia teologiczne pod kierunkiem mistrza Benedykta Hessego i już w roku 1429 jako bakałarz teologii otrzymał prawo wykładania na tymże Wydziale. Wtedy to właśnie, zgodnie z obowiązującym zwyczajem uniwersyteckim, został kanonikiem kantorii św. Floriana w Krakowie i otrzymał związaną z nią prebendę w postaci probostwa w Olkuszu. Z obu zaszczytów zrezygnował niemal zaraz, uważając zapewne, że dochody otrzymywane z tytułu członkostwa w Collegium Maius są dlań zupełnie wystarczające. Świadczy to dobitnie o tym, że jedynie racje intelektualne i wrodzona pobożność kazały mu pogłębić wiedzę o Bogu. W ciągu $10 \mathrm{z}$ górą lat przeszedł po kolei wszystkie etapy cursus sacrae Scripturae, poznał dokładnie treść Pisma św., zgłębił obowiązkowe cztery księgi Sentencji Piotra Lombarda. Temu wszystkiemu musiało towarzyszyć prowadzenie dysput teologicznych, a po uzyskaniu bakalaureatu z teologii kierowanie zajęciami młodszych adeptów teologii. Jednocześnie był profesorem na Wydziale Artium, a jako kapłan wypełniał swoje obowiązki duszpasterskie, głosił kazania itp. Nic więc dziwnego, że teologiczne studia Jana Kantego trwały aż do roku 1443. Kiedy otrzymał tytuł doktora teologii, liczył Kanty 54 lata. Nie wiadomo jednak, w jakim czasie i czy w ogóle objął katedrę teologii, którą do swej śmierci (1456) piastował jego mistrz Benedykt Hesse. Zawsze bowiem tytułował się: „collega magistrorum Collegii Artistarum".

Przy tym nieustannie zajmował się kopiowaniem traktatów teologicznych. W wieku sześćdziesięciu kilku lat sporządził dwa tomy pism Ojców Kościoła (głównie św. Augustyna, Grzegorza Wielkiego, Bernarda i innych autorów), przepisał dwie pierwsze części Summy teologicznej i Summy przeciwko poganom - dzieł św. Tomasza. W tymże też czasie zaczął przepisywać obszerny komentarz do św. Mateusza pióra Benedykta Hessego. Była to już ostatnia, jak się zdaje, praca Jana Kantego jako skryptora. Ukończył ją w styczniu 1463 roku, czyli w wieku 74 lat.

Sledząc rozwój tej intelektualnej aktywności mistrza z Kęt nieodparcie nasuwa się pytanie o jego uczniów i to zarówno o uniwersyteckich wychowanków, jak i tych, którzy w latach dwudziestych XV stulecia opuścili mury szkoły klasztornej w Miechowie, kierowanej, jak wiadomo, przez Jana Kantego w latach 1421 - 1429. Otóż z nich tylko jeden, choć bezimienny, pozostawił trwałą wiadomość o tym, że wysłuchał cyklu wykładów mistrza Jana na temat gramatyki Donata, pozostawiając skrypt z tych wykładów (1423). Natomiast imiona uczniów Kantego z czasów jego pracy na uniwersytecie są nam znane jedynie 
na zasadzie domniemania. Można bowiem przyjąć, że byli nimi przede wszystkim bakałarze i magistrzy Wydziału Artium, promowani przez niego w okresie dziekaństwa. Wymieńmy tylko kilka imion bardziej znanych. I tak w grudniu 1432 r. otrzymał promocję na magistra artium późniejszy profesor na tym Wydziale - Paweł Pelczar z Krakowa; takoż Jakub z Lgoty, zapewne współkolega Kantego w czasie studiów teologicznych, w których Jakub doszedł jedynie do stopnia bakałarza; wreszcie Mathias de Strigonia (Strzegom), bakałarz uniwersytetu wiedeńskiego. Bakałarzami (marzec 1433) i magistrami sztuk wyzwolonych (grudzień 1437), promowanymi przez Jana Kantego, a więc z pewnością również jego uczniami byli m. in.: doktor dekretów i kanonik gnieźnieński Albertus de Lissecz, późniejszy profesor teologii w Krakowie Mikołaj Ligatoris, a także inni, którzy zaznaczyli się w różny sposób w dziejach krakowskiej uczelni, jak np. Jakub z Lisowa, Mikołaj Leimiter z Krakowa, Maciej z Głogowa, Stanisław z Goździkowa. Było ich oczywiście znacznie więcej. Warto może jeszcze wspomnieć o jednym, z którym Jana Kantego musiały z czasem połączyć więzy przyjaźni, skoro Jan Kanty miał być jednym z wykonawców jego testamentu. Mowa o młodszym odeń, ale nie mniej sławnym koledze - Janie z Dąbrówki. Być może do tej grupy uczniów i przyjaciół mistrza z Kęt należał także „frater Isaias de s. Katherina”, czyli Izajasz Boner. Ten ostatni, wraz $\mathrm{z}$ innymi świątobliwymi mężami piętnastowiecznego Krakowa, tworzył grono bliskich przyjaciół mistrza Jana z Kęt; tradycja, utrwalona już w XVI wieku przez krakowskiego profesora Jana z Trzciany, połączyła w bliżej nieokreśloną konfraternię: Stanisława Kazimierczyka, Jana z Dukli, Michała Giedrojcia, Świętosława Milczącego, Szymona z Lipnicy, a „z wieku i urzędu” przewodził jej Jan Kanty.

Działalność uniwersytecko-pisarska patriarchy krakowskiego nie była jedynym terenem, na którym wykazał on swą aktywność. Był przecież również kapłanem, kaznodzieją i spowiednikiem. Jaki stopień dynamizmu osiągnęła duszpasterska działalność mistrza z Kęt i jaki był jej zasięg na terenie krakowskim, tego możemy się tylko domyślać, już to na podstawie osobistych zapisek Kantego, już to opierając się na tradycji wyrosłej wokół jego osoby. Przeglądając jego rękopisy pod tym kątem widzenia, stwierdzamy szczególne zainteresowanie Kantego zagadnieniami penitencjalnymi, kultem i znaczeniem Eucharystii oraz potrzebą głoszenia słowa Bożego. Dwie pierwsze grupy problemów omawia Kanty bądź w luźnych uwagach marginalnych, bądź też w dłuższych wypisach, stanowiących syntetyczne omówienie kwestii tytułowej. Są to naturalnie notatki kompilacyjne, przeznaczone do wykorzystania w nauczaniu szkolnym, na ambonie lub w konfesjonale. Jeśli zaś chodzi o kazania, to zebrał je w czterech tomach. Stanowią one kolekcję około 600 tekstów de tempore i de sanctis, powstałą niemal w całości w pierwszej połowie lat trzydziestych XV stulecia. W ogromnej większości mamy tu kazania jego wspólczesnych kolegów uniwersyteckich lub profesorów, np. Mikołaja z Kozłowa, Mikołaja Scul- 
tetusa de Conradisilva, Jana Elgota, Pawła z Zatora, ale też kopiował teksty dawniejszych autorów (św. Augustyna, Bernarda, Jakuba de Voragine). Naturalnie nieodparcie nasuwa się pytanie o oryginalną twórczość predyktatorską Jana Kantego. Niestety mistrz z Kęt nie zostawił nam w tym względzie żadnej wskazówki. Jedno tylko nie ulega wątpliwości, że skopiowane kazania musiał wygłaszać po polsku, o czym świadczą glosy polskie, wielokrotnie znajdywane we wspomnianych kodeksach.

Skoro już napomknęliśmy o oryginalnej twórczości naszego Patrona, to dodajmy, że ogranicza się ona jedynie do tzw. casus conscientiae, choć z całą pewnością musiały jeszcze istnieć inne jego samodzielne prace naukowe, co wynikało $\mathrm{z}$ regulaminu studiów uniwersyteckich. Po tych ostatnich ślad jednak wszelki zaginął. Co się zaś tyczy casus conscientiae, rzecz wyglądała następująco. Zgodnie z ówczesnymi zwyczajami profesorowie uniwersyteccy mieli obowiązek rozstrzygania kwestii penitencjalnych, z jakimi zwracali się do nich różni spowiednicy. Jan Kanty opracował kilka takich krótkich rozwiązań. Jego teologiczna wiedza, ugruntowana na praktycyzmie Augustyna i racjonalizmie Tomasza, pozwoliła mu sformułować rozwiązania dylematu sumienia w duchu życiowego rozsądku, wyrozumiałości i dobroci. Nie bez powodu nazwano go w rękopisie, zawierającym owe casus conscientiae — „magister bonus”. Siła oddziaływania tej dobroci musiała być w istocie niezwykła, skoro właśnie ona, a nie akademicka działalność pozostała przewodnią nicią legendy o życiu tego profesora Uniwersytetu Krakowskiego. Ta sama legenda podbudowuje wielką pobożność Kantego do cierpiącego Chrystusa i Matki Bożej wiadomościami o jego rzekomych pielgrzymkach do Ziemi Świętej, do Rzymu, do Loretto. Niestety nie znajdujemy nigdzie potwierdzenia tych pątniczych podróży. Przecież jako ewenement raczej niecodzienny musiałyby one pozostawić po sobie jakiś ślad w rękopisach mistrza $\mathrm{z}$ Kęt, odnotowującego w marginaliach często mniej ważne czy wręcz błahe wydarzenia ze swego życia.

Ostatni raz imię mistrza z Kęt pojawiło się w dokumencie z 8 października 1473 , a więc na niecałe trzy miesiące przed śmiercią. Z tych ostatnich lat nie dochował się żaden rękopis z jego skryptornii. Zapewne osłabiony wieloletnim wysiłkiem wzrok mistrza $\mathrm{z}$ Kęt nie pozwalał mu już na kontynuowanie pracy kopisty. Zresztą kończyła się epoka książki pisanej i Jan Kanty musiał zdawać sobie sprawę z dokonującej się przemiany w warsztacie naukowym przyszłego uczonego. Nie wykluczone, że w ostatnim miesiącu swego życia oglądał pierwszą książkę drukowaną w Krakowie, tj. Kalendarz astronomiczny na rok 1474, dzieło wędrownego drukarza z Bawarii - Kaspra Straubego.

Mistrz Jan z Kęt umierał w Boże Narodzenie roku 1473. Odchodziła z ziemskiego padołu osobistość znana szerokim kręgom uniwersyteckim i mieszczańskim piętnastowiecznego Krakowa. Opinia świętości, otaczająca jego osobę jeszcze za życia, skłoniła władze uniwersyteckie do złożenia zwłok Sługi Bożego w akademickim kościele św. Anny. Od tej chwili nie minęło półtora roku, 
kiedy tamtejszy proboszcz, jednocześnie były rektor krakowskiego Studium Generalnego Maciej z Kościana uznał za swój obowiązek spisanie cudów dokonujących się przy grobie mistrza z Kęt. Żywiołowość czci, jaką mieszkańcy ówczesnego Krakowa otoczyli jego grób, musiała przybrać znamiona powszechności o niespotykanej sile religijnego oddziaływania. Podobnie spontanicznym kultem otoczono w XV wieku tylko osobę królowej Jadwigi. Znamienność tego faktu pobudza do głębokiej refleksji.

Kiedy dzisiaj, po sześciuset latach, wracamy myślą do postaci św. Jana Kantego, dogmat o świętych obcowaniu nabiera szczególniejszej treści. Aby lepiej w nią wniknąć, należało w porządku przyrodzonym uwolnić ludzkie oblicze Swięte od sztucznej aureoli i zniekształcających je pseudohistorycznych rekwizytów. Dopiero wtedy możemy zrozumieć, w jak harmonijną współzależność łączy się pierwiastek Boski i ludzki w osobie naszego Patrona. Dlatego też Swięty, którego czcimy, to nie tylko przeszłość, ale i teraźniejszość. U źródeł kultu jego osoby tkwi głębokie przekonanie, że i dzisiaj jest on czynny w naszych sprawach i że poprzez granice śmierci możemy z nim utrzymywać łączność duchową oraz czerpać zeń zachętę i pomoc w postaci wstawiennictwa u Boga. Myśl ta towarzyszyła również przeszłym pokoleniom. Znamiennym tego świadectwem jest kazanie ks. Jacka Liberiusza, proboszcza od Bożego Ciała w Krakowie, wygłoszone w okresie wielkiego postu roku 1667. Oto jak aktualne i dzisiaj myśli zawarł ks. Liberiusz w zakończeniu swego kazania o Janie Kantym, wówczas jeszcze nawet nie beatyfikowanym:

„Daj Panie Boże na przyczynę tego światobliwego męża b. Kantego, podten sejm Polakom twoim serca klarowne jako woda, aby uważali, co powinni Panu Bogu, Kościotowi, Panu, aby uważali szczerze potrzeby Ojczyzny, y prywatne porzuciwszy interressa zabiegali co prędzey ostatniey zgubie Oyczyzny swoiey [...]. Wylewamy dla Boga [...] serca nasze wziqwszy za przyczyńce tego stuge Bożego b. Jana Kantego; prosimy pokornie, aby królestwa tego, dziedzictwa swego, w kościoty tak rozmnożonego, w stugi Boże, w katoliki tak obfitego, nie dawat bestyom pogańskim [...], aby [...] Akademiey, miastu temu dat tę pociechę, ̇̇eby przezeń y przez przyczynę jego ratowat utrapiona Oyczyznę”.

PS. W 42. numerze „Tygodnika Powszechnego” z 21 października 1990 roku ukazał się artykuł Pana Redaktora Tadeusza Ż y ch i ew i cza pt. Profesor Jan z Kęt, opublikowany również z racji wspomnianej rocznicy. Niestety, jest to artykuł ideowo i merytorycznie zupełnie chybiony. Zawiera bowiem wiele błędów historycznych i fantazyjnych twierdzeń przy kompletnej nieznajomości najnowszych opracowań na temat św. Jana Kantego. Innego zaś rodzaju przykrym znamieniem omawianego artykułu jest zupełne zlaicyzowanie pięknej postaci tego Kapłana Chrystusowe go. Autor bowiem jednym słowem nie wspomniał o tym, że Mistrz z Kęt należał do stanu duchownego. To zatajenie prawdy o s a cru m uważam za sprawę zasadniczą. Dlatego w tej krótkiej notatce chciałbym dać wyraz memu krytycznemu stanowisku wobec bezwartościowych tez naukowych i ideowych, zawartych w artykule Pana Żychiewicza. Jednocześnie żywię (spodziewam się, że nie plonną) nadzieję, iż uznany powszechnie autorytet wybitnego publicysty „Tygodnika Powszechnego" nie usankcjonuje tym razem nieprawdy o św i ę t y m ,profesorze Janie z Kęt". 


\section{DE VITA S. IOANNIS CANTII QUID NUNC CENSEATUR}

\section{Argumentum}

Hoc anno MDCCCCXC sescentesimum anniversarium nativitatis s. Ioannis Cantii (MCCCXC - MCCCCLXXIII) celebramus. Ille vir divus suam vitam in terra Deo ut presbyter, scientiarum vero artibus ut professor ordinarius in Alma Universitate Cracoviensi gratificatus erat. De vita eius multa adhuc nostris praesertim temporibus scripta sunt. Anno MDCCCXC suum libellum de vita nostri Patroni Divi Vladislaus Wisłocki, rerum gestarum scriptor ac valde meritus bibliothecarius Cracoviensis, in lucem edidit. Sententiam eius de anno et die nativitatis s. Ioannis Cantii (de Kęty) falsam quidem et nullis testimoniis probandis demonstratam puto. Nihil quoque valet opinio eiusdem auctoris, qui contra ipsum Cantium nec non contra totam usque ad nostra tempora traditionem affirmaverit, tamquam et non in villa Kęty (in dioecesi Cracoviensi), sed in vicino Malec s. Ioannes Cantius natus sit. Praeterea nullus biographus Ioanni de Kęty familiae nomen Vacenga, quo eius pater — ut dicitur - appellabatur, ascribere potest, quod saeculo XIV et $\mathrm{XV}$ in Polonia nomen familiae vel cognomen nulla occasione data a patre hereditarium fuerat.

Haec et aliae opiniones Vladislai Wisłocki, quamquam nullam historicis rationem habuerint, heu a nonnullis auctoribus identidem nunc quoque repetantur. Adversum quos ego argumenta quaedam protuli. Etiam de s. Ioannis Cantii vitae fatis nec non de eius bibliotheca XXVIII volumina continente, quae manu eius propria fere in toto conscripta erant et hodie in Bibliotheca Jagellonica Cracoviae atque Bibliotheca Vaticana asservantur, narravi. S. Ioannes Cantius plurimis colophonis, qui in his codicibus exstant, multas nobis de sua vita aut de minoris momenti rebus gestis informationes praebet. Conspectum novissimorum librorum, qui de omnibus his rebus et quibusdam aliis, quae ad Ioannis Cantii vitam, studia operaque pertinent, supra in annotatione prima (1) praesto. 